\title{
Sintesis Tetrapeptida Linear Phe-Leu-Ala-Pro (FLAP) sebagai Kandidat Antioksidan dengan Metode Solid Phase Peptide Synthesis (SPPS)
}

\author{
Eka Nurjanah", Nety Kurniaty \\ Prodi Farmasi, Fakultas Matematika dan Ilmu Pengetahuan Alam, \\ Universitas Islam Bandung, Indonesia. \\ *eka.nurzannah12@gmail.com, netykurniaty@yahoo.com
}

\begin{abstract}
Antioxidants are compounds that can prevent or inhibit oxidation in a cell caused by free radicals. Based on previous study, one of the natural antioxidant peptides is a tetrapeptide (Phe-LeuAla-Pro), which was isolated from Sea Cucumber Collagen (Acaudina Molpadiodes) in Zheijing Province, China. In this study, a tetrapeptide (Phe-Leu-Ala-Pro) has been successfully synthesized using the solid phase peptide synthesis method (SPPS) with the strategy by using a protective group Fmoc, 2-chlorotrityl chloride resin as a buffer and coupling reagents including HBTU, HOBt and DIPEA. FLAP tetrapeptide compound has been formed which is characterized by mass spectrophotometer with an $\mathrm{m} / \mathrm{z}$ value of 447.2608 for peak of $[\mathrm{M}+\mathrm{H}]+$ ion. The results of the RPHPLC analysis showed that the FLAP tetrapeptide compound was not pure because there were still minor peaks, the target compound retention time was 2 minute. The FLAP tetrapeptide compound has antioxidant activity with an IC50 value of $9376.6 \mathrm{ppm}$ based on DPPH test.
\end{abstract}

Keywords: Tetrapeptide FLAP, Antioxidant, Solid Phase Peptide Synthesis (SPPS).

\begin{abstract}
Abstrak. Antioksidan adalah suatu senyawa yang dapat mencegah atau menghambat oksidasi pada suatu sel yang disebabkan oleh radikal bebas. Salah satu peptida antioksidan alami yang ditemukan pada penelitian sebelumnya adalah tetrapeptida (Phe-Leu-Ala-Pro) yang diisolasi dari Kolagen Teripang (Acaudina Molpadiodes) di Provinsi Zheijing Cina yang memiliki aktivitas antioksidan. Pada penelitian ini tetrapeptida (Phe-Leu-Ala-Pro) telah berhasil disintesis menggunakan metode sintesis peptida fase padat (SPPS) dengan strategi pemakaian gugus pelindung Fmoc, penyangga yaitu resin 2-klorotritil klorida dan reagen pengkopling diantaranya yaitu HBTU, HOBt dan DIPEA. Senyawa tetrapeptida FLAP telah terbentuk yang ditandai dengan hasil karakterisasi menggunakan spektrofotometer massa dengan nilai $\mathrm{m} / \mathrm{z}$ 447,2608 pada puncak ion $[\mathrm{M}+\mathrm{H}]+$. Pada hasil analisis RP-HPLC menunjukkan bahwa senyawa tetrapeptida FLAP belum murni karena masih adanya puncak-puncak minor, senyawa target berada pada waktu retensi menit ke-2. Senyawa tetrapeptida FLAP memiliki aktivitas antioksidan dengan nilai IC50 sebesar 9376,6 ppm pada uji DPPH.
\end{abstract}

Kata Kunci: Tetrapeptida FLAP, Antioksidan, Sintesis peptida fase padat (SPPS). 


\section{A. Pendahuluan}

Peptida bioaktif yang telah menarik banyak perhatian para ilmiah memiliki efek potensial untuk kesehatan dan mengurangi resiko penyakit seperti yang diketahui yang memiliki aktivitas antioksidan, antikanker hingga antimikroba (Sumiarsa, 2019). Selain itu peptida merupakan bahan yang tersusun dari asam amino sehingga lebih selektif sekaligus relatif lebih aman ditoleransi oleh tubuh (Fosgerau dan Hoffmann, 2015).

Menurut Jin, et. al,. (2019) menyatakan bahwa telah dilakukan isolasi salah satu peptida antioksidan yang diperoleh dari Kolagen Teripang Acaudina Molpadiodes di Provinsi Zheijing di Cina merupakan salah satu derivat tetrapeptida dengan urutan FLAP (Phe-Leu- AlaPro) dengan IC50 pada uji DPPH 0,385 mg/mL. Dari hasil penelitian sebelumnya, tetrapeptida hasil isolasi dengan urutan asam amino FLAP menunjukkan aktivitas antioksidan yang kurang baik.

Pada penelitian sintesis tetrapeptida dengan urutan asam amino FLAP (Phe-Leu-AlaPro) sebagai kandidat antioksidan. Dilakukan sintesis secara kimia sebagai metode alternatif dari ekstraksi bahan alam yang membutuhkan waktu cukup lama untuk mendapatkan senyawa target, maka dilakukan sintesis peptida agar memudahkan mendapatkan senyawa target yang memiliki aktivitas farmakologi yang sama. Selain itu sintesis peptida memiliki keuntungan yaitu pelarut yang digunakan nya sedikit dan bahan yang digunakan diperoleh dari asam amino sehingga tidak dianggap benda asing oleh tubuh. Metode sintesis kimia senyawa tetrapeptida urutan asam amino FLAP menggunakan metode sintesis peptida fase padat (SPPS), dimana metode SPPS merupakan suatu metode sintesis peptida yang efektif dan sederhana (Irwansyah, 2010).

Maka rumusan masalah pada penelitian ini adalah bagaimana cara mensintesis tetrapeptida FLAP (Phe-Leu- Ala-Pro) menggunakan metode SPPS agar didapat urutan seperti hasil isolasi. Selain itu apakah senyawa tetrapeptida (Phe-Leu-Ala-Pro) hasil sintesis memiliki aktivitas antioksidan terhadap radikal DPPH seperti yang dimiliki oleh peptida hasil isolasi dari Teripang Acaudina Molpadiode. Tujuan dari penelitian ini yaitu untuk mensintesis senyawa tetrapeptida FLAP dengan metode SPPS dan menguji aktivitas antioksidan tetrapeptida FLAP hasil sintesis menggunakan metode peredaman DPPH (2,2-difenil-1-pikrilhidrazil). Manfaat penelitian ini yaitu dapat mengembangkan metode alternatif sintesis tetrapeptida FLAP yang dapat menghasilkan senyawa yang memiliki aktivitas antioksidan.

\section{B. Metodologi Penelitian}

Penelitian ini menggunakan metode sintesis peptida fase padat (SPPS) yang terdiri dari beberapa tahap yaitu melakukan pengkondisian tabung agar bebas dari pengotor supaya tidak menggangu proses sintesis, pengembangan resin dilakukan untuk membuka sisi aktif resin agar memudahkan asam amino masuk kedalam resin. Selanjutnya kopling asam amino pertama pada resin untuk penyangga fasa padat, kemudian untuk mengetahui keberhasilan proses pengkoplingan maka dilakukan uji kloranil, lalu capping resin agar dapat menutupi gugus aktif resin maka resin tidak berikatan dengan asam amino lain. Setelah itu pelepasan gugus pelindung Fmoc agar terjadi pengikatan antara asam amino dengan asam amino lainnya. Selanjutnya penyusunan asam amino dengan melakukan prosedur yang sama untuk proses pengkoplingan asam amino hingga terbentuk senyawa tetrapeptida yang diinginkan. Setelah terbentuk fragmen tetrapeptida selanjutnya dilakukan pelepasan tetrapeptida dari resin, setelah terlepas kemudian dilakukan proses pengeringan dan pemekatan menggunakan rotary evaporator. Kemudian proses karakterisasi menggunakan spektrofotometer massa untuk memastikan terbentuknya senyawa tetrapeptida, lalu dilakukan uji kemurnian dengan melihat kromatogram menggunakan RP-HPLC. Lalu uji aktivitas antioksidan menggunakan metode peredaman DPPH dengan Spektrofotometer UV-Vis untuk mengetahui nilai aktivitas peredaman radikal bebas dengan nilai IC50.

\section{Hasil Penelitian dan Pembahasan}

Sintesis senyawa FLAP menggunakan metode sintesis peptida fase padat . Keuntungan metode ini diantaranya yaitu lebih sederhana dan dapat memproduksi senyawa yang diinginkan dengan 
cepat (Kim \& McAlpine, 2013). Resin 2- klorotiril klorida adalah resin fase padat yang digunakan pada metode sintesis, resin dikembangkan terlebih dahulu agar sisi aktif pada resin terbuka sehingga asam amino pertama dapat lebih mudah terikat pada sisi aktif resin. Pelarut yang digunakan yaitu diklorometana (DCM) dan dimetilformamida (DMF).

\section{Pengkoplingan Asam Amino}

Pada sintesis asam amino pertama pada tetrapeptida FLAP yaitu asam amino Prolin (Pro). Asam amino pada terminal $\mathrm{n}$ sudah terlindungi dengan gugus pelindung Fmoc agar tidak mengganggu reaksi, proses reaksi yang terjadi adalah asam amino pertama Fmoc-Pro-OH dengan DIPEA sebagai reagen yang bersifat basa. Reaksi asam basa hanya mengambil hidrogen dari gugus karboksil pada asam amino Fmoc-Pro-OH membentuk nukleofil, kemudian nukleofil tersebut yang terbentuk akan menggantikan atom klorida pada karbon kuartener yang ada pada resin 2-klorotritil klorida. Sehingga asam amino dapat membentuk ikatan dengan resin (Maharani, et. al., 2016).

Reaksi dilakukan selama 4 jam untuk sintesis peptida FLAP, untuk memastikan asam amino pertama yang masuk kedalam resin. Nilai loading resin menentukan jumlah asam amino yang dapat ditambahkan selanjutnya (Chan dan White, 2000). Penentuan nilai loading resin dilakukan dengan menggunakan spektrofotometer UV dan telah diketahui nilai loading resin peptida FLAP yaitu $0,3626 \mathrm{mmol} / \mathrm{g}$ dimana hasil dari loading resin menandakan bahwa resin dapat mengikat asam amino dengan baik karena berada pada rentang rata-rata loading resin yaitu 0,1-1,3 $\mathrm{mmol} / \mathrm{mg}$ (Maharani, et. al., 2016). Dilakukan capping resin untuk menutupi gugus aktif resin agar tidak bereaksi dengan gugus metoksi untuk menghindari asam amino lain bereaksi dengan gugus aktif resin yang tersisa. Proses capping resin menggunakan campuran metanol : DCM : DIPEA $(2: 7: 1)$, dimana metanol berperan yang menutupi sisi aktif pada gugus klorida, kemudian DCM sebagai pelarut yang bersifat volatil dan DIPEA sebagai basa yang menarik $\mathrm{OH}$ dari metanol agar lebih nukleofil yang menyerang karbon tersier dari resin.

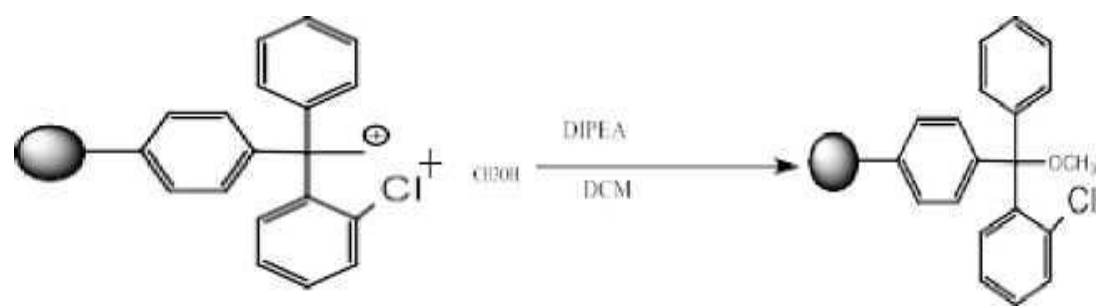

Gambar 1. Reaksi Capping Resin dengan Reagen Methanol dan DIPEA.

\section{Deproteksi Fmoc}

Pelepasan gugus pelindung Fmoc dilakukan setelah capping resin. Deproteksi dilakukan untuk menyediakan sisi aktif asam amino pertama yang akan bereaksi dengan asam amino selanjutnya, dimana gugus pelindung Fmoc yaitu bersifat labil dalam kondisi basa sehingga dapat dilepaskan dengan menggunakan basa (Sumiarsa, 2019). Dengan menggunakan larutan piperidin 20\% dalam DMF, dipilih DMF karena memiliki sifat yang tidak volatil. Hidrogen pada cincin fluorena dalam gugus Fmoc diikat oleh piperidin yang membentuk gugus asam amino bebas (Chan dan White, 2000). Untuk mengetahui keberhasilan deproteksi Fmoc dilakukan uji kloranil yang ditandai dengan adanya perubahan warna pada butiran resin karena adanya gugus $\mathrm{NH}_{2}$ bebas yang berikatan dengan kloranil yang menyebabkan berubah warna (Sumiarsa, 2019).

\section{Penyusunan Tetrapeptida}

Tahap selanjutnya adalah reaksi kopling dengan asam amino kedua, Fmoc-Ala-OH dengan menambahkan HBTU dan HOBt dimana kedua reagen tersebut merupakan reagen yang sering digunakan untuk proses pengkoplingan asam amino, karena dapat menjadikan gugus amina pada asam amino menjadi lebih reaktif dan terjadinya proses reaksi yang cepat. HBTU dianggap sebagai reagen kopling yang biasanya dapat menunjukkan performa yang sangat baik sedangkan HOBt dapat meningkatkan rendemen (Valeur dan Bradley, 2009). 
Tahap pelepasan gugus pelindung Fmoc dilakukan kembali dengan penambahan piperidin 20\% dalam DMF. Dan diuji keberhasilan kopling dengan uji kloranil yang menunjukkan tidak adanya perubahan warna pada resin karena masih ada gugus pelindung Fmoc yang membuat gugus amina belum bebas. Lakukan tahap pengulangan reaksi kopling dan deproteksi Fmoc untuk asam amino ketiga (Fmoc-Leu-OH) dan asam amino keempat (Fmoc-Phe-OH) secara berurutan sampai terbentuk tetrapeptida.

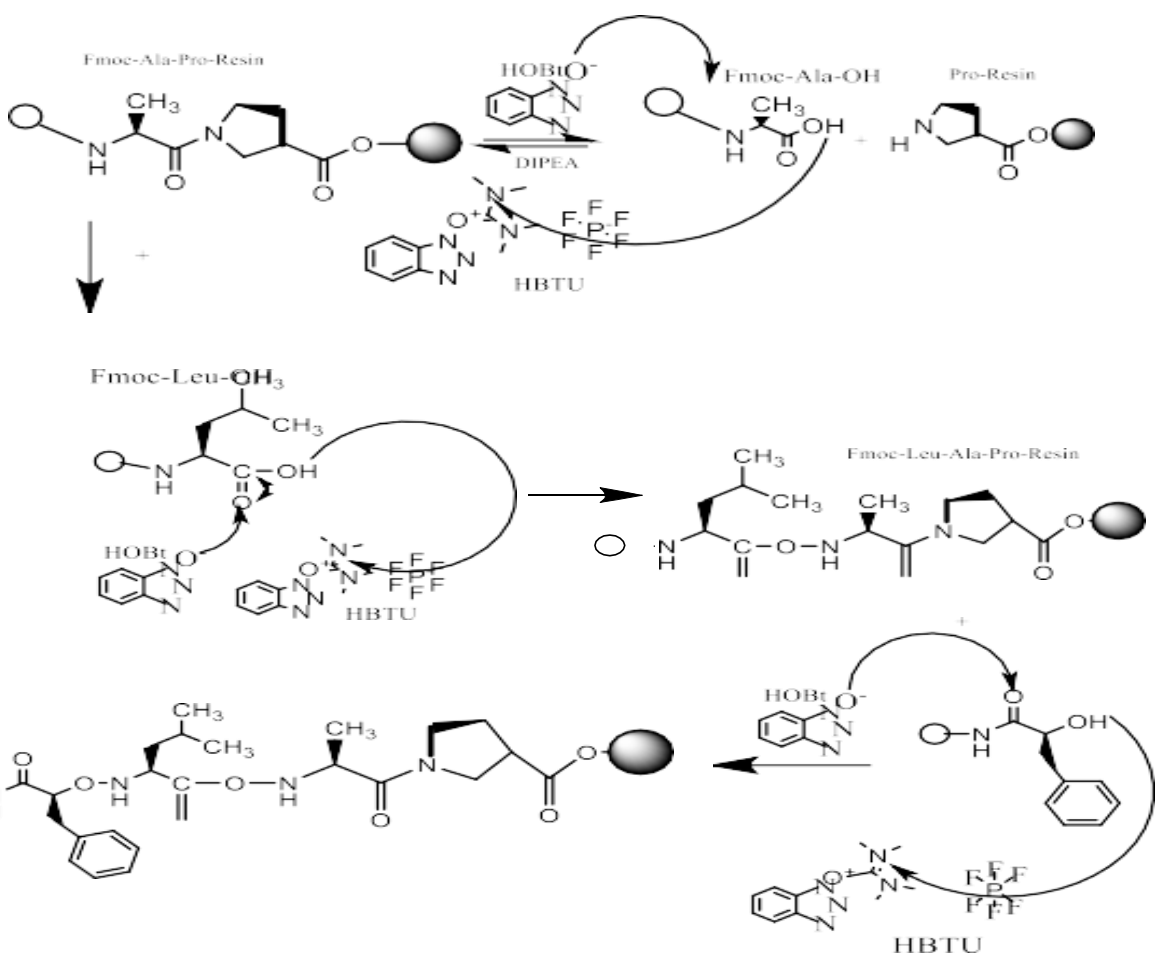

Gambar 2. Reaksi Pengikatan Tetrapeptida Menggunakan HBTU dan HOBt.

\section{Pelepasan Peptida dari Resin}

Tetrapeptida yang telah disintesis kemudian dilepaskan dari resin. Pelepasan tetrapeptida dari resin dengan menggunakan TFA 20\% dalam DCM. Dimana TFA memiliki gugus amino yang bermuatan positif, gugus amino ini dapat memotong ikatan resin pada tetrapeptida, dimana TFA yang bersifat asam sedangkan resin 2-klorotritil klorida bersifat basa sehingga proses lepasnya resin yaitu dengan membentuk garam TFA yang memiliki kelarutan rendah sehingga TFA dapat terhambat pada tabung sintesis dan dapat terpisah dengan tetrapeptida (Chan dan White, 2000). Keberhasilan proses pelepasan resin ditandai dengan berubahnya warna resin menjadi merah yang menunjukkan bahwa resin sudah terlepas. Setelah dipekatkan dengan rotary evaporator, krud peptida diperoleh sebanyak 204,6 mg sebagai selai warna kuning kecoklatan.

Reaksi yang terjadi pada pelepasan resin dimulai dari protonasi atom oksigen pada rantai peptida oleh TFA maka dapat menghasikan rantai peptida (Chan dan White, 2000). 


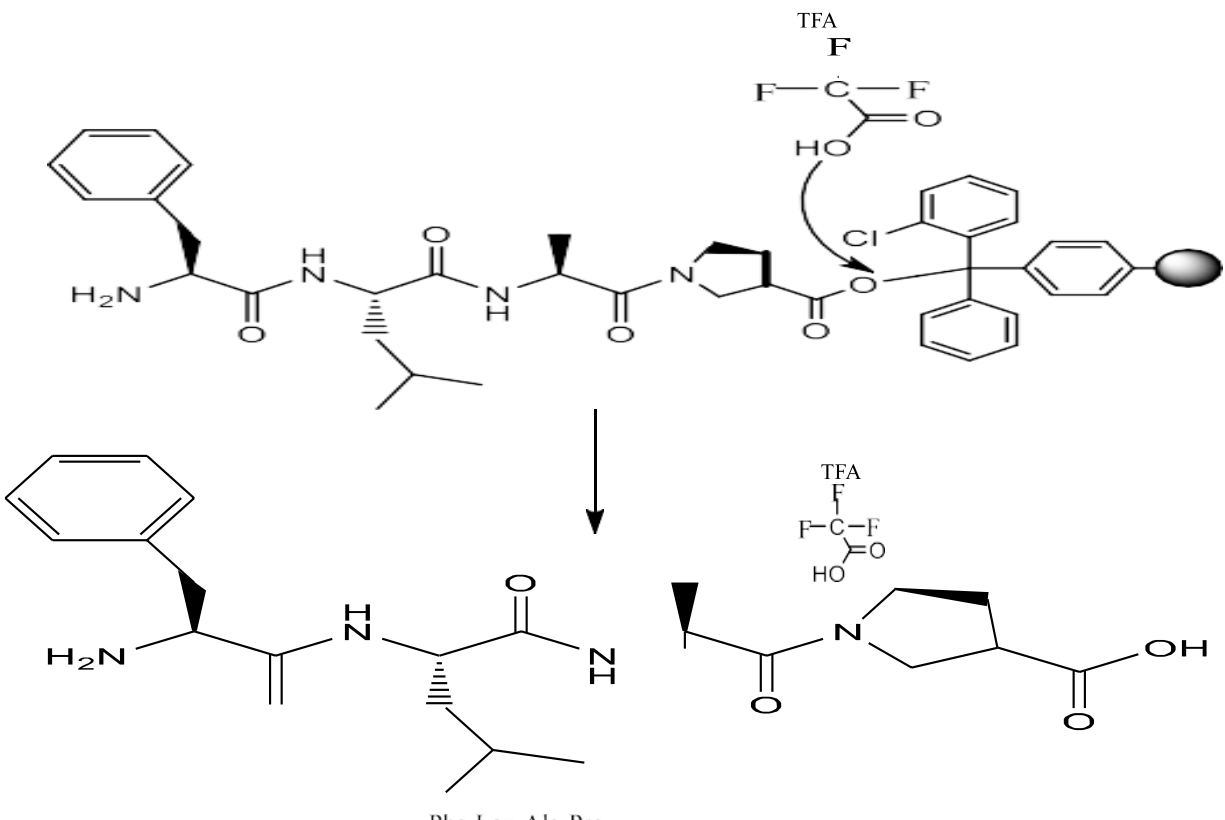

Phe-Leu-Ala-Pro

Gambar 3. Reaksi Pemutusan Resin

Dalam sintesis tetrapeptida FLAP urutan asam amino yang terdapat dalam peptida sudah diketahui secara pasti sehingga untuk karakterisasi dapat digunakan metode spektroskopi massa untuk mengetahui bobot molekul dari produk sintesis. Pada penelitian digunakan Spektrometer Massa. Hasil karakterisasi menunjukkan adanya puncak ion molekul untuk senyawa FLAP dengan nilai m/z 447,2608.

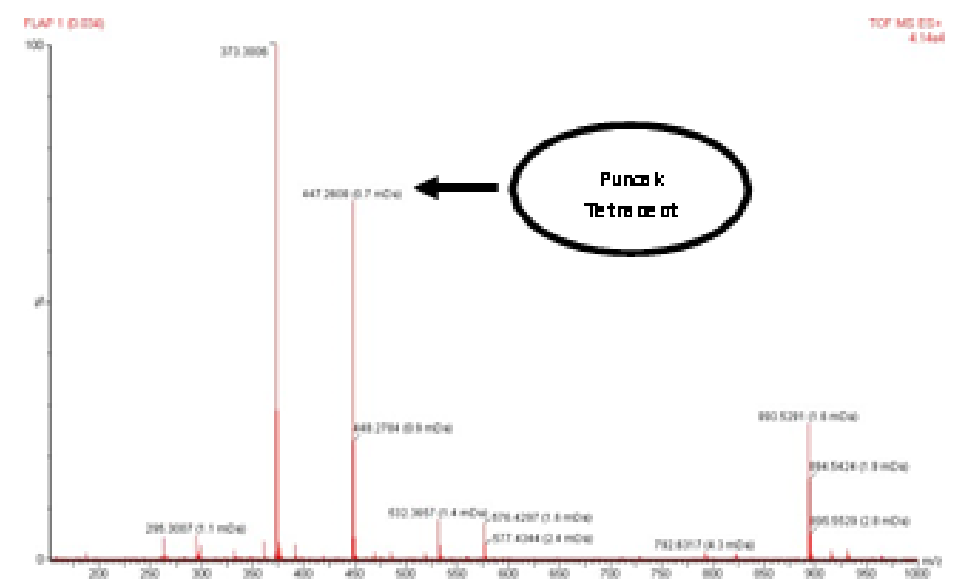

Gambar 4. Hasil Spektrofotometer Massa Tetrapeptida(Phe- Leu-Ala-Pro).

Peptida FLAP yang didapat yaitu 204,6 mg kemudian diambil sebanyak $1 \mathrm{mg}$ dilarutkan dalam aquadest : acetonitril (1:1). Untuk pengujian dengan RP- HPLC dilakukan menggunakan fase balik C18 menggunakan eluen gradien air : acetonitril, dengan detektor PDA dan UV pada panjang gelombang $210 \mathrm{~nm}$ dan $240 \mathrm{~nm}$. Deteksi peptida dalam RP-HPLC antara panjang gelombang $210 \mathrm{~nm}$ sampai $254 \mathrm{~nm}$, dimana panjang gelombang tersebut panjang gelombang spesifik untuk ikatan peptida. 


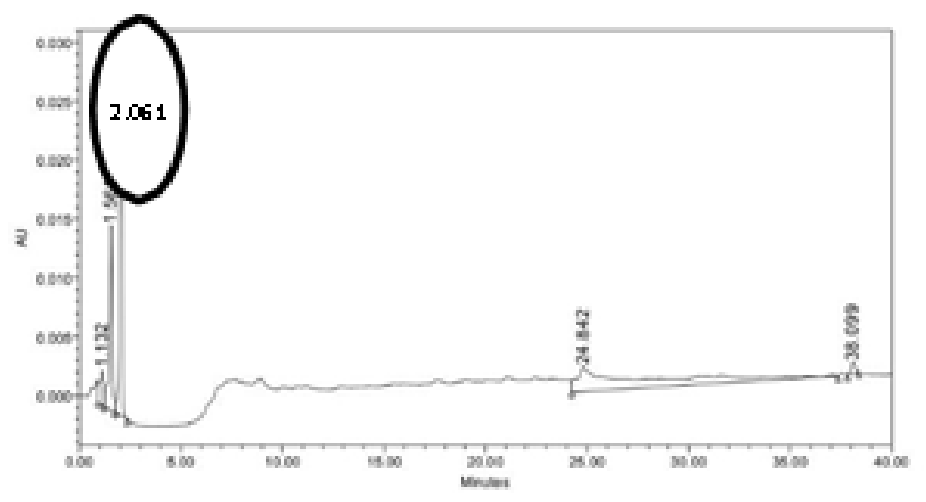

Gambar 5. Hasil RP-HPLC tetrapeptida FLAP pada panjang gelombang $240 \mathrm{~nm}$

Berdasarkan hasil tersebut dapat menunjukkan bahwa hasil kromatogram tetrapeptida yang didapat waktu retensi pada menit ke 2,061 dan membentuk beberapa puncak. Hal tersebut menandakan bahwa peptida belum murni sehingga memerlukan pemurnian lagi.

\section{Uji Aktivitas Antioksidan metode DPPH}

Pengujian antioksidan tetrapeptida FLAP menggunakan metode peredaman DPPH, metode peredaman DPPH adalah metode yang mudah dan cepat untuk mengevaluasi senyawa antioksidan secara spektrofotometri, metode ini juga merupakan metode yang sensitif dan sederhana (Molyneux, 2004). Prinsip pengujian ini adalah atom hidrogen senyawa antioksidan akan berikatan dengan elektron bebas senyawa radikal yang menyebabkan perubahan radikal menjadi non radikal ditandai dengan perubahan warna ungu menjadi kuning.

Pengujian aktivitas antioksidan dibuat dalam $20460 \mathrm{ppm}$ dengan menggunakan konsentrasi yaitu 0 ppm, 1600 ppm, 8000 ppm, 10000 ppm, dan 15000 ppm untuk mengetahui tingkat peredaman warna sebagai akibat adanya senyawa antioksidan yang mampu mengurangi intensitas warna ungu dari DPPH karena semakin banyaknya senyawa antioksidan akan menyebabkan semakin besar peredaman warna ungu dari DPPH sehingga nilai absoransi yang diperoleh semakin kecil. Kemudian larutan didiamkan selama 30 menit agar terjadi reaksi antara radikal DPPH dan sampel uji selanjutnya ukur absorbansinya menggunakan spektrofotometer UV-Vis pada panjang gelombangnn $517 \mathrm{~nm}$ dimana panjang gelombang tersebut merupakan panjang gelombang maksimum dari DPPH. Hasil yang diperoleh menunjukkan uji aktivitas yang lemah karena nilai absorbansi yang besar, dimana semakin besar nilai absorbansi maka nilai $\mathrm{IC}_{50}$ semakin lemah (Erawati, 2012).

Melalui hasil uji DPPH didapatkan nilai IC50 adalah 9376,6 $\mu \mathrm{g} / \mathrm{mL}$, Berdasarkan nilai IC50 yang didapat bahwa senyawa tetrapeptida FLAP memiliki aktivitas antioksidan yang lemah, bahwa tingkat kekuatan senyawa yang memiliki aktivitas antioksidan terhadap DPPH yaitu aktivitasnya lemah jika memiliki nilai IC50 > $150 \mu \mathrm{g} / \mathrm{mL}$ (Armala, 2009).

Tabel 1. Hasil Uji Aktivitas Senyawa Tetrapeptida FLAP

\begin{tabular}{|c|c|c|c|}
\hline Konsentrasi (ppen) & ABS & $\%$ inhibisi & $\operatorname{ICS0}(\mathrm{ppen})$ \\
\hline 0 & 1,7156 & 0 & \\
\hline 1600 & 0,9798 & 42,941 & \\
\hline 8000 & 0,6332 & 63,092 & 9376,6 \\
\hline 10000 & 0,7584 & 55,794 & \\
\hline 15000 & 0,7976 & 53.909 & \\
\hline
\end{tabular}

Pada pengujian aktivitas antioksidan digunakan pembanding yaitu vitamin $\mathrm{C}$, Tujuan dilakukan pembanding vitamin $\mathrm{C}$ untuk melihat tingkat aktivitas antioksidan dari senyawa tetrapeptida linier FLAP. Berdasarkan hasil yang diperoleh bahwa nilai IC50 Vitamin C yaitu 6,6057 ppm, dimana hasil yang diperoleh bahwa aktivitas antioksidan sampel lebih lemah dari 
pembanding.

Tabel 2. Hasil Uji Aktivitas Antioksidan Vitamin C

\begin{tabular}{|c|c|c|c|}
\hline Konsentrasi (ppm) & $\mathrm{ABS}$ & $\%$ inhibisi & IC50 (ppm) \\
\hline 0 & 0,8517 & 0 & \\
\hline 1 & 0,7472 & 12,2695 & 6,6057 \\
\hline 10 & 0,2198 & 74,1927 & \\
\hline
\end{tabular}

\section{Kesimpulan}

Berdasarkan penelitian ini dapat diambil kesimpulan bahwa tetrapeptida Phe-Leu-Ala-Pro dapat disintesis dengan menggunakan metode sintesis peptida fase padat (SPPS) dengan hasil karakterisasi menggunakan spektrofotometer telah menunjukkan adanya puncak ion molekul $[\mathrm{M}+\mathrm{H}]$ pada $\mathrm{m} / \mathrm{z} 447,2608$ dan hasil yang diperoleh dari uji aktivitas antioksidan dan pada tetrapeptida FLAP didapatkan nilai IC50 sebesar $9376,6 \mu \mathrm{g} / \mathrm{mL}$ sehingga aktivitas antioksidan dari senyawa tersebut lemah.

\section{Acknowledge}

Penulis mengucapkan terima kasih kepada Universitas Islam Bandung dan Lab Sentral Universitas Padjadjaran yang telah memberikan fasilitas untuk melakukan penelitian.

\section{Daftar Pustaka}

[1] Armala, M. M. 2009. Daya Antioksidan Fraksi Air Ekstrak Herba Kenikir (Cosmos caudatus H.B. K) dan profil KLT. Skripsi, 39. Yogyakarta: Fakultas Farmasi Universitas Islam Indonesia

[2] Chan, W. C., 2000. Fmoc Solide Phase Peptide Synthesis A Practical Approach. New York: Oxford University press.

[3] Erawati. 2012. Uji Aktivitas Antioksidan Ekstrak Daun Garciniadaedalanthera Pierre dengan Metode DPPH (1.1 difenil pikrihidrazil) dan Identifikasi Golongan Senyawa Kimia dari Fraksi Paling Aktif, Skripsi. Depok: FMIPA, Universitas Indonesia.

[4] Fosgerau, K. Hoffman. T., 2015. Peptide therapeutics currents status and future direction. Denmark.

[5] Irwansyah, 2010. Studi Struktur Self-Asembly Peptida Ampifil. Jakarta:Universitas Indonesia Khopkar,S.M. (1990). Konsep Dasar KImia Analitik: Jakarta UI Press.

[6] Jin, H. X. Xu. H. P. Li. Y. Zhang. Q. W. \&. Xie., H. 2019. Preparation and evalution of peptides with potentional antioxidant activity by microwave assisted enzymatic hydrolysis of collagen from sea cucumber acaudina molpadioides obtained from Zheijiang Province in China, Marine drugs, 17 (3), 169.

[7] Kim, S. McAlpine. S., R. 2013. Solid Phase versus Solution Phase Synthesis of Heterocyclic Macrocycles. J. Molecules, Vol 8: 1111-1121.

[8] Maharani, R. Yanti. E. F., 2016. Sintesis Heptapeptida Linear (H-Tyr-Asp-Pro-AlaProPro-Pro-OH) dengan menggunakan Dic/Oksima sebagai reagen pengkopling. Bandung: Departemen Kimia Fakultas Matematika dan Ilmu Pengetahuan Alam Universitas Padjadjaran Bandung.

[9] Molyneux, P. 2004. The Use of The Stable Free Radical Diphenylpicryl-hydrazyl (DPPH) for Estimating Antioxidant Activity, Songklanakarin J. Sci. Technol, 212-217

[10] Sumiarsa, D. Marpaung. C., Zainuddin. A., Hidayat. T.A., Harneti. Maharani., R. dkk. 2019. Sintesis Tetrapeptida PADY menggunakan Metode Fasa Padat dan Aktivitas Antioksidannya. Departemen Kimia Fakultas Matematika dan Ilmu Pengetahuan Alam Universitas Padjadjaran Bandung: Jurnal Kimia Valensi.

[11] Valeur E, Bradley M. 2009. Amide bond formation: beyond the myth of copling reagents. 8 | Eka Nurjanah, et al. Volume 1, No. 2, Tahun 2021, Hal: 1-4 ISSN: 2798-6292 Chem. Soc. 
96 | Eka Nurjanah, et al.

Rev. 38: 606-631. 